\title{
Potential Inhibitor Against Phase Separation, 1,6-hexanediol Specifically Binds to Beta Actin in Nuclear Extract of Human Cell Line
}

\author{
Naomi Ueda ${ }^{1}$, Yuki Hirose ${ }^{2}$, Ryoma Yoneda ${ }^{1}$, Toshikazu Bando ${ }^{2}$, Riki Kurokawa ${ }^{1,}$, \\ ${ }^{1}$ Division of Biomedical Sciences, School of Medicine, Saitama Medical University, Saitama, Japan \\ ${ }^{2}$ Department of Chemistry, Graduate School of Science, Kyoto University, Kyoto, Japan
}

Email address:

rkurokaw@saitama-med.ac.jp (R. Kurokawa)

*Corresponding author

\section{To cite this article:}

Naomi Ueda, Yuki Hirose, Ryoma Yoneda, Toshikazu Bando, Riki Kurokawa. Potential Inhibitor Against Phase Separation, 1,6-hexanediol Specifically Binds to Beta Actin in Nuclear Extract of Human Cell Line. Biomedical Sciences. Vol. 6, No. 4, 2020, pp. 89-97. doi: $10.11648 /$ j.bs.20200604.13

Received: October 8, 2020; Accepted: October 24, 2020; Published: November 4, 2020

\begin{abstract}
RNA-binding protein (RBP) TLS/FUS plays a major role in induction of phase separation/phase transition and aggregation in relation to familial amyotrophic lateral sclerosis (ALS). Recently, organelles without lipid-bilayer membrane including stress granule, Cajal body, and nucleolus are found to be formed by the phase separation. The phase separation is an event that solutions with two solvents separate into two distinctive phases. The phase separation is prone to have solid phase and forms harmful precipitation or aggregation against living cells, indicating that the phase separation has both benefit and risk on cellular programs. Thus, it is essential for utilization of the phase separation in divergent cellular programs to control or inhibit the undesirable precipitation in living cells. Here, we analyze an inhibitory mechanism of the phase separation and precipitation. Inhibition of the phase separation is one of a critical regulatory step to prevent dysregulation of the phase separation and resulting deleterious precipitations. An inhibitory agent against the phase separation, amphiphilic alcohol, 1,6-hexanediol (1,6-HD) has been reported to examine function of phase separations. Thus, affinity chromatography of biotinylated 1,6-HD is employed to identify an initial event induced by 1,6-HD. Upon successful synthesis of biotinylated compounds of 1,6-HD (bio-1,6-HD), the affinity chromatography with bio-1,6-HD has been established at this study. The bio-1,6-HD captured protein bands on SDS-PAGE gel from HeLa cell nuclear extracts. The bands were analyzed with mass spectrometric analyses, showing that the proteins should be cytoskeleton related proteins. Further analysis using specific antibodies revealed one of the bands as human beta actin. It has been shown that beta actin is involved in divergent cellular activities including the phase separation and also neuronal functions like long-term potentiation. Therefore, beta actin might initiate the 1,6-HD-induced inhibition of the precipitation, although more experiments should be required to test whether it actually works in living cells.
\end{abstract}

Keywords: TLS, FUS, Phase Separation, Phase Transition, Aggregation, Precipitation, 1,6-hexanediol

\section{Introduction}

RNA-binding protein TLS (translocated in liposarcoma)/FUS (fused in sarcoma) is a causative gene for amyotrophic lateral sclerosis (ALS) $[1,2]$ and frontotemporal lobar degeneration (FTLD) [3]. Clinical symptoms of ALS are characterized by the impairment of upper and lower motor neurons, indicate muscle atrophy, and gradually spreading to the muscle of whole body including respiratory system. At the late stage of the ALS, patients suffering from the difficulty of speaking and breathing terminally die from the respiratory failure $[4,5]$. More than $90 \%$ of ALS is sporadic disorder in which no genetic background is identified $[4,5]$. Around $10 \%$ of ALS is familial disease. The causative genes of familial ALS reported are the superoxide dismutase-1 [6], TDP-43 [7], and TLS [1, 2]. We have been 
focusing on TLS from a point of view of gene expression regulation. Mutated forms of TLS genes indicate the similar pathology with other ALS causative genes, which is dislocation into cytoplasm from nucleus, exhibiting the aberrant cytoplasmic inclusions. TLS binds RNA in specific and non-specific manners, and plays pivotal roles in RNA metabolisms in processing, and transport of RNA [8,9]. Mutations in TLS might cause failure of these RNA metabolic functions, suggesting its function as a mediator for biologically active RNA molecules.

Chemical library screening of an agent to induce embryonic stem cells into myocardial cells provided isoxazole [10]. A biotinylated compound, biotinylated isoxazole (BISOX) was produced to capture binding molecules to isoxazole. Unexpectedly, BISOX induced precipitation of proteins from cultured cell lysates [11], and the precipitation contained more than hundreds of RBPs [11-14]. Many of these proteins are components of RNA-protein assemblies forming in nuclei of living cells, called RNA granules or membraneless organelles. Many proteins in these structures contain heterogeneous nuclear ribonucleoprotein $\mathrm{K}$ (hnRNP K) homology $(\mathrm{KH})$ domain and RNA recognition motif (RRM) $[15,16]$ as well as low complexity sequences or intrinsically disordered regions (IDR) $[14,17]$. One of these proteins turned out to be TLS The IDRs in these proteins are susceptible for BISOX mediated aggregation, and later the IDRs are shown to undergo a phase separation or phase transition to a hydrogel-like state even without BISOX. X-ray crystallography and electron microscopic observation demonstrated that the hydrogels form with the amyloid-like fiber structures. Unlike pathogenic amyloid fibers, the IDR-based polymers shown are reversible structures. These observations present an outline for understanding the function of IDRs as well as an organizing principle for cellular structures without membrane, or, membraneless organelles [11]. These data present a forthcoming direction of phase separation towards biological investigations.

TLS forms liquid compartments, droplets or condensates in nuclei and also in the cytoplasm when exposure to divergent environment related to ALS [18-22]. In vitro reconstitution experiments indicated that the liquid droplets of TLS convert from a liquid state to an aggregated one over hours $[2,8,9,23]$. This conversion is accelerated by ALS patient-derived mutations. These data confirm that the physiological role of TLS needs to form dynamic droplets [18]. It has been suggested that function of TLS as liquid-like compartments requires risk of accidental aggregation in cells [18]. Then, this aberrant phase transition of the droplets of TLS into aggregates is a potential cause for ALS.

Precipitation of proteins is recently emerging as a central concerns regarding various disorders related to neurodegenerative diseases like amyotrophic lateral sclerosis (ALS) and frontotemporal lobar degeneration (FTLD) [1, 2, 8, 23-26]. It has been well recognized that precipitation of proteins in living cells causes disturbance of biological processes and gives rise to neurodegenerative diseases in the neurons. More clinical impact to these neuronal disorders enhances investigation of precipitated RNA-binding proteins that intimately link to the diseases [27-30]. We have developed experimental systems to investigate TLS to analyze the precipitation with making a model system to assess the involvement of the precipitation into the neurodegenerative diseases. Published data from others and ours indicate that BISOX effectively precipitates divergent RNA-binding proteins including TLS $[11,12,14]$.

The BISOX precipitation assay system works well to assess the phase separation and subsequent precipitation of TLS and also to examine functions of the precipitation of TLS. The phase separation has a beneficial aspect in biological programs, but also bears a harmful adverse effect suffering from subsequent precipitation. It is likely that any regulatory mechanism to suppress formation of the precipitation subsequent to the phase separation of TLS. We hypothesize an inhibitory system against the phase separation-induced precipitation functioning in living cells. Previous studies reported that 1,6-hexanediol (1,6-HD) melts the droplets forming by phase separation [31-34]. We take advantage of 1,6-HD to explore the inhibitory and regulatory system for phase separation and precipitation.

We initiate an experiment to detect any binding protein to 1,6-HD using its biotinylated compounds and found beta actin from the nuclear extract of cultured human cell lines. Based on the data shown here, we have discussed the possible roles of cytoskeleton molecule beta actin on the inhibitory mechanism and presented a model of the regulation of the phase separation and precipitation.

\section{Materials and Methods}

\subsection{Antibodies and Reagents}

Mouse anti-TLS/FUS antibody (611385, Lot no. 2209827) was purchased from BD Biosciences (New Jersey, USA). Rabbit anti-TLS/FUS antibody (11570-1-AP) was purchased from Protein Tech (Illinois, USA). Rabbit human beta actin antibody was purchased from St John's Laboratory (London, United Kingdom, STJ 91464, Lot. 1464901). Rabbit anti-mouse HRP conjugated IgG (P0161, 20017456) was purchased from Dako (Glostrup, Denmark). Goat anti-rabbit HRP-conjugated IgG (7074S, 25) was purchased from Cell Signaling Technology (Massachusetts, USA). Biotinylated isoxazole (BISOX), 6-(((5-(2-Thienyl) -1,2-oxazol-3 -yl) carbonyl)amino)hexyl,5-(2-oxohexahydro-1H-thieno [3,4-d] imidazol-4-yl) pentanoate (biotin-isoxazole; BISOX) was produced following the protocols [12]. HeLa cell nuclear extract (NE) was prepared as previously described protocol [35-38].

\subsection{Synthesis of Biotinylated Compounds.}

\subsubsection{General Procedure}

Reagents and solvents were purchased from standard 
suppliers and used without further purification. HPLC analysis was performed on a Jasco Engineering PU-2089 plus series system using a COSMOSIL $150 \times 4.6 \mathrm{~mm}$ 5C18-MS-II Packed Column (Nacalai Tesque, Inc., Kyoto, Japan) in $0.1 \%$ TFA in water with acetonitrile as the eluent at a flow rate of 1.0 $\mathrm{mL} / \mathrm{min}$ and a linear gradient elution of $0-100 \%$ acetonitrile in $20 \mathrm{~min}$ with detection at $205 \mathrm{~nm}$. Collected fractions were analyzed by MALDI-TOF-MS microflex-KS II (Bruker, Massachusetts, USA). Flash column purification was performed on CombiFlash Rf RFJ model (Teledyne Isco, Inc., Nebraska, USA) with RediSep ${ }^{\circledR}$ Rf 26g C18 Reverse phase column. $0.1 \%$ TFA in water with acetonitrile was used as the solvent (gradient/ acetonitrile 0\%: 0-4 min, 0-30\%: 4-45 min, 30\%: 45-50 min, 100\%: 50-55 min, 80\%: 55-60 min). HPLC purification was carried out by Jasco engineering PU-2080 plus series using a COSMOSIL $150 \times 10 \mathrm{~mm}$ 5C18-MS-II Packed Column (Nacalai Tesque, Inc.) in $0.1 \%$ TFA in water with acetonitrile as the eluent at a flow rate of $3.8 \mathrm{~mL} / \mathrm{min}$ and a linear gradient elution of $+1 \% / \mathrm{min}$ acetonitrile for $20 \mathrm{~min}$ with detection at $205 \mathrm{~nm}$. 1H NMR spectra were recorded on JEOL JNM ECA-600 spectrometer (600 MHz for $1 \mathrm{H})$, with chemical shifts reported in parts per million relative to residual solvent and coupling constants in hertz. The following abbreviations were applied to spin multiplicity: s (singlet), d (doublet), dd (double doublet), t (triplet), q (quartet), quin (quintet) and $\mathrm{m}$ (multiplet).

\subsubsection{Biotinylated 1,6-hexanediol (bio-1,6-HD).}

(+)-Biotin $(20.8 \mathrm{mg}, 85.1 \mu \mathrm{mol})$ was dissolved in $3 \mathrm{~mL}$ of $\mathrm{N}, \mathrm{N}$-dimethyformamide (DMF) and 1,6-hexanediol $(97.7 \mathrm{mg}$, 10 equiv.), 1- (3-Dimethylaminopropyl) -3-ethylcarbodiimide hydrochloride (EDCI, $31.4 \mathrm{mg}, 2$ equiv.), 4-Dimethylaminopyridine (DMAP, $10.3 \mathrm{mg}, 1$ equiv.), and $\mathrm{N}, \mathrm{N}$-diisopropylethylamine (DIEA, $83.5 \mu \mathrm{L}, 6$ equiv.) was added. The mixture was stirred at $60^{\circ} \mathrm{C}$ for 26.5 hours. Then the solvent was evaporated and dried in vacuo. The remained oil was dissolved in $\mathrm{H}_{2} \mathrm{O}$ and lyophilized. Lyophilized sample was washed by diethyl ether $\left(\mathrm{Et}_{2} \mathrm{O}\right)$ and brown oil was precipitated. After $\mathrm{Et}_{2} \mathrm{O}$ was removed in vacuo, $93.2 \mathrm{mg}$ of brown oil was obtained. This oil was purified by flash column Collected fractions were lyophilized and $24.1 \mathrm{mg}$ of target material was obtained $(70.0 \mu \mathrm{mol}$, yield: $82 \%)$. 1H NMR (600 MHz, DMSO-d6): $\delta 6.44(\mathrm{~s}, 1 \mathrm{H}), 6.39(\mathrm{~s}, 1 \mathrm{H}), 4.31$ (t, J=6.3 $\mathrm{Hz}, 1 \mathrm{H}), 4.14$ (t, J=5.1 Hz, 1H), 3.70-3.63 (m, 5H), 3.24-3.17 $(\mathrm{m}, 2 \mathrm{H}), 3.10(\mathrm{q}, \mathrm{J}=6.2 \mathrm{~Hz}, 1 \mathrm{H}), 3.05$ (quin, $\mathrm{J}=7.5 \mathrm{~Hz}, 2 \mathrm{H}$ ), $2.82(\mathrm{dd}, \mathrm{J}=12.0 \mathrm{~Hz}, 4.8 \mathrm{~Hz}, 1 \mathrm{H}), 2.54(\mathrm{~d}, \mathrm{~J}=7.8 \mathrm{~Hz}, 1 \mathrm{H})$, $1.88-1.80(\mathrm{~m}, 2 \mathrm{H}), 1.65-1.59(\mathrm{~m}, 1 \mathrm{H}), 1.57-1.52(\mathrm{~m}, 2 \mathrm{H})$, 1.51-1.44 (m, 1H), 1.40-1.33 (2H, m), 1.09 (quin, $\mathrm{J}=6.6 \mathrm{~Hz}$, $4 \mathrm{H})$. Analytical HPLC: $\mathrm{tR}=8.4 \mathrm{~min}$.

The related figure (Figure 5) is shown in Appendix.

\subsubsection{Biotinylated PEG (polyethyleneglycol)12-NH- hexanol (bio-1,6-HD plus).}

This compound has a spacer between biotin portion and hexanol (1,6-HD plus)

EZ-LinkTM NHS-PEG12-Biotin $250 \mathrm{mM}$ in DMF 21.25 $\mu \mathrm{L}(5.3 \mu \mathrm{mol})$ was mixed with $128.3 \mu \mathrm{L}$ of DMF, 6-amino-1-hexanol (0.78 mg, 1.2 equiv.), and DIEA (1.08 $\mu \mathrm{L}, 1.2$ equiv.) and then stirred at room temprature for 2.5 hours. The mixture was purified by reverse-phase HPLC and $3.2 \mathrm{mg}$ of target material (colorless oil) was obtained (3.4 $\mu \mathrm{mol}$, yield: $64 \%$, analytical HPLC: $\mathrm{tR}=9.3 \mathrm{~min}$. MALDI-TOF MS: m/z calcd for $\mathrm{C} 43 \mathrm{H} 83 \mathrm{~N} 4 \mathrm{O} 16 \mathrm{~S}+[\mathrm{M}+\mathrm{H}]+$ 943.54, found; 943.55).

The related figure (Figure 6) is shown in Appendix.

\subsection{Affinity Chromatography with Biotinylated Compounds of 1,6-HD.}

The biotinylated materials binding assays were performed as previously described [36-38]. Briefly, it has shown below. Dynabeads-M280 (Dynabeads: Thermo Fisher, Massachusetts, USA) was washed with PBS containing 0.02\% Tween 20 . Fifty $\mu \mathrm{g}$ of bio-1,6-HD was added to the beads and incubated for $15 \mathrm{~min}$ at room temperature with rotation. Subsequently, the beads were incubated with $\mathrm{NE}$ at $4^{\circ} \mathrm{C}$ with rotation for 1 to $5 \mathrm{~h}$ shown in text. The beads were then washed three times in $1 \mathrm{ml}$ of WCE buffer and resuspended in SDS sample buffer and boiled at $100^{\circ} \mathrm{C}$ for $2 \mathrm{~min}$. Finally, the beads were removed and supernatants were applied to SDS-poly acrylamide gel electrophoresis (SDS-PAGE) following for stain with coomassie brilliant blue (CBB) based staining reagent of the SimplyBlue ${ }^{\mathrm{TM}}$ SafeStain (Thermo Fisher) or Western blotting analyses.

The beads-prebound with biotinylated 1,6-HD compounds were incubated with bacterial lysates containing glutathione s-transferase (GST)-fused-human beta actin in $1 \mathrm{mM}$ ATP, 50 $\mathrm{mM} \mathrm{KCl}, 1 \mathrm{mM} \mathrm{CaCl}_{2}$, and $1 \mathrm{mM} \mathrm{MgCl}_{2}$ at room temperature for five hours. After the incubation, the beads were washed three times with WCE buffer, and boiled in SDS-Sample buffer for $2 \mathrm{~min}$. The samples were analyzed on SDS-PAGE above shown, following the Western blot with rabbit anti-human beta actin antibody.

\subsection{Protein Analysis}

SDS-polyacrylamide gel electrophoresis was performed with $10 \%$ gels following CBB staining [36-38]. Western blotting was done with anti-TLS monoclonal antibody with the dilution ratio 1:2000 using standard protocol shown previously [37].

The protein samples were separated by SDS-PAGE and identified with $\mathrm{CBB}$ staining. Protein bands were excised from the gel, digested with trypsin and subjected to nano-LC/MS/MS analysis by standard protocol [39] (Japan Proteomics Co.Ltd, Sendai, Japan).

\section{Results}

\subsection{Inhibitory Activity of 1,6-hexanediol on the Phase Separation and Aggregation Induced by BISOX}

To show inhibitory effect of 1,6-HD on phase separation and resulting aggregation or precipitation of TLS, we have exploited a BISOX-induced precipitation system. Treatment of NE with $100 \mu \mathrm{M}$ BISOX effectively precipitated TLS at $4^{\circ} \mathrm{C}$ for 1 hour. The precipitates were detected by a Western 
blot with specific antibody against human TLS (Figure 1, lane 2-4). Then, addition of 1,6-HD as $10 \%$ solution to the BISOX reaction inhibited the precipitation, and at $15 \%$ of 1,6-HD, it inhibited the BISOX-induced TLS precipitation more effectively (Figure 1, lane 5 and 6). These data clearly indicate that 1,6-HD exerts inhibitory activity on the BISOX-induced phase separation and subsequent precipitation of TLS.

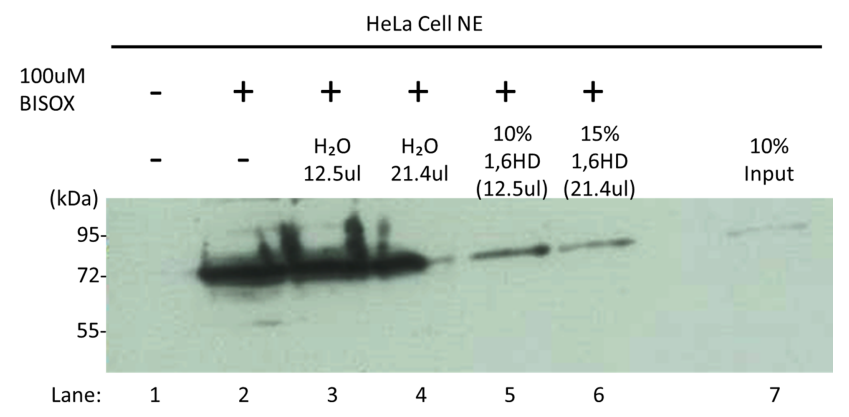

Figure 1. Inhibitory activity of 1,6-hexanediol on the phase separation and aggregation induced by BISOX. The samples of these lanes are depicted the top of the gel image. $N E(50 \mu l)$ was added to each lane.

\subsection{Identification of Biotinylated 1,6-HD (bio-1,6-HD) Bound Proteins in NE with the Affinity Chromatography.}

Next we attempted to capture molecules that are directly bound with 1,6-HD in NE. For this purpose, an affinity chromatography with biotinylated 1,6-HD (bio-1,6-HD) need to be established with synthesis of bio-1,6-HD (Materials and Methods, Figure 2A). At a first experiment, any significant binding was not detected on a SDS-PAGE gel of CBB staining with a protocol containing steps of incubation of pre-bound bio-1,6-HD on magnetic beads containing streptavidin with NE. Then, we designed bio-1,6-HD with spacer molecules, biotinylated PEG (polyethylene glycol)12-NH-hexanol (bio-1,6-HD plus, Figure 2A). Then, we set reactions with NE with bio-1,6-HD and bio-1,6-HD plus (bio-1,6-HD compounds). During the incubation, the bio-1,6-HD compounds are supposed to bind to molecules contained in NE. Then, the reactions of bio-1,6-HD compounds and NE were incubated with the streptavidin magnetic beads to separate the molecules bound with bio-1,6-HD compounds. The protein fractions bound-bio-1,6-HD compounds on the magnetic beads were boiled to release the proteins to analyze with a SDS-PAGE gel. The SDS-PAGE gel with $\mathrm{CBB}$ staining indicated a specific protein band at the lane 4 of bio-1,6-HD plus (Figure 2B). The band was excised as a peace and analyzed for mass spectrometry. This experiment demonstrated that the band should be human beta actin. It should be cautious to see if the binding of the 1,6-HD plus to beta actin is specific or not, because beta actin, a cytoskeleton protein, is ubiquitously expressed and also extremely abundant in all kinds of eukaryotic cells.
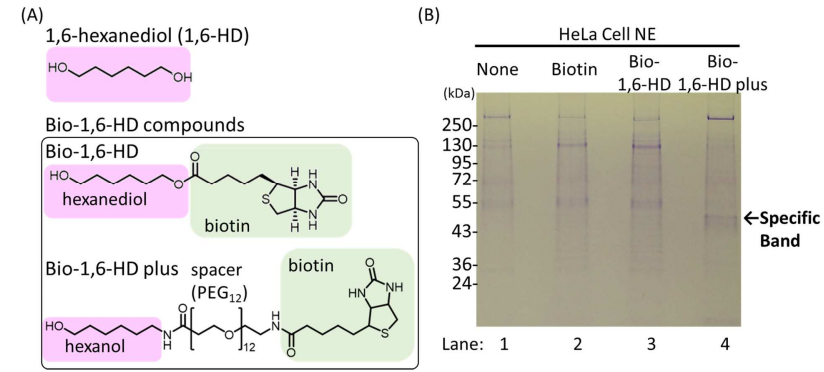

Figure 2. Identification of bio-1,6-HD plus-bound proteins in NE with the affinity chromatography. (A) Structural formula of 1,6-HD, Biotinylated 1,6-HD (Bio-,1,6-HD), and Bio-1,6-HD plus. (B) The lanes contain bio-1,6-HD compounds shown at the top of the lanes. Fifty $\mu g$ of biotinylated compounds was added to each reaction.

\subsection{Confirmation of Beta Actin Binding to Bio-1,6-HD Compounds with Specific Antibody Against TLS of a Western Blot}

Further analysis of the bound fraction from the affinity chromatography of bio-1,6-HD compounds with NE has been executed. Western blot experiments with antibody against beta actin detected firm signal from the sample with the fraction from the affinity chromatography, indicating that bio-1,6-HD plus should specifically bind to beta actin (Figure 3 , lane 4).

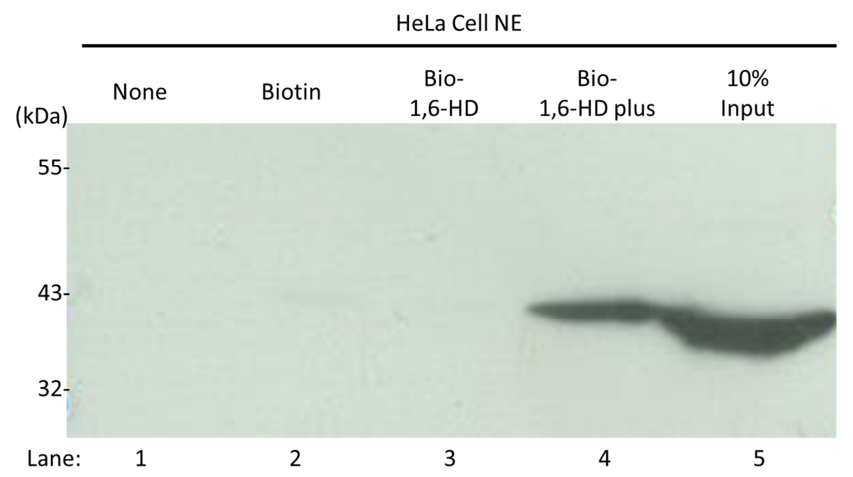

Figure 3. Confirmation of beta actin binding to bio-1,6-HD plus with specific antibody against beta actin of Western blot.

We designed bacterial expressed beta actin binding assay with GST-human beta actin. GST-beta actin in reactions was incubated with bio-1,6-HD compounds. After the incubation, the Western blot detected specific signal on the lane of bio-1,6-HD plus, indicating that GST-beta actin binds to bio-1,6-HD plus (Figure 4, lane 4). These data confirm that the interaction of bio-1,6-HD plus with beta actin in NE should be functional, although we need to have more experiments to examine biological significance of binding of 1,6-HD to beta actin to know physiology of beta actin in living cells. This will prompt us to obtain a whole figure of contribution of beta actin to regulation of phase separation in cells. 


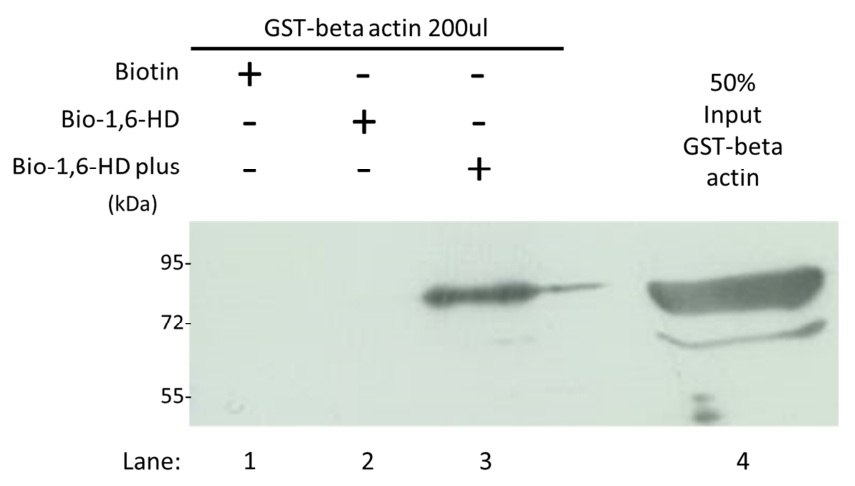

Figure 4. Confirmation of the GST-beta actin binding to bio-1,6-HD compounds with Western blot using beta actin antibody. Fifty $\mu g$ of biotinylated compounds was added to each reaction.

\section{Discussion}

Recent studies have been revealed significant impact of phase separation on biological programs rapidly [40-45]. Phase separation has been found to be involved in divergent cellular functions including formation of various membrane-less organelles [46-49], cellular mobility [50, 51], and transcriptional regulation [52-54]. Contrarily, negative side of phase separations is derived from consequential precipitation of RBPs including TLS. One of major concerning is a cause for neurodegenerative disease like Alzheimer disease [55-57], frontotemporal dementia [3, 58], and ALS [1, 2, 20, 59, 60]. Dysregulation of phase separation has harmful influences [61] on many cellular programs also regarding neuronal functions causing these neurodegenerative diseases. Therefore, it is likely that safety systems against dysregulation of phase separation should work in living cells. It might be inhibitory mechanism for phase separation. We have initiated experiments to identify molecules targeted by 1,6-HD, putative inhibitor against phase separation [31, 32, 34]. In this study, we have demonstrated evidence regarding regulatory systems based upon inhibition of the precipitation induced by phase separation. Unexpectedly, we detected specific binding of 1,6-HD to beta actin using affinity chromatography experiments. This presents a hypothesis regarding divergent functions of beta actin and regulation of phase separation. We discuss this unanticipated relationship between beta actin and 1,6-HD later in this section.

To validate regulatory systems of phase separation in cells, 1,6-HD is employed to assess inhibitory mechanism of phase separations. This reagent functions as a deterrent to lysis cellular membranes. Permeability of lipid bilayer membranes of 1,6-HD has been documented already by Finkelstein in 1976 [62]. It was expected that 1,6-HD should permeate and melt cellular membranes of eukaryotic cells. The McKnight group has focused this permeability of 1,6-HD to disassemble IDR polymer of RBPs [34]. The toxic, C9orf72 gene-encoded Proline Arginine (PRn) poly-dipeptide binds divergent intracellular targets mainly consisting of the IDR polymers of RBPs [27, 28]. Actually, 1,6-HD melted the IDR polymers and intracellular puncta, assemblies of the PRn poly-dipeptides with intermediate Filaments. The PRn-poly-dipeptides which are encoded by C9orf72 hexanucleotide expansions, has been identified in the lesion sites of ALS. The PRn poly-dipeptides bind to polymer of IDR proteins like TLS, and might cause ALS.

At neutral $\mathrm{pH}$ and physiological ionic strength TLS prompts its IDR to polymerize into labile, cross-beta fibers to form amyloid-like polymers, hydrogel droplets. Treatment of the TLS hydrogels with 1,6-HD resulted in melting them down. The same result was obtained also with another RBP, hnRNPA2. Previous studies have indicated that the PRn and Glycine-Arginine (GRn) poly-dipeptides encoded by C9orf72 repeat expansion bind to hydrogels composed of amyloid-like polymers of the IDRs of various RBP including hnRNPA2 and TLS [63]. The PRn exhibits more enhanced interaction with polymeric forms of IDRs than their unfolded, monomers. This suggests that the PRn interaction should be a cause for neurodegenerative disease ALS. On the other hands, 1,6-HD breaks the interaction of PRn and IDRs of RBPs. This implies that 1,6-HD could be a seed for drug development against ALS.

Incubation of the HA-tagged PR20 peptides with the 20 $\mathrm{kDa}$ IDR of hnRNPA2 resulted in immunoprecipitation with a HA antibody. Addition of 1,6-HD at $6 \%$ reduced interaction of HA-tagged PR20 with the IDR of hnRNPA2. This clearly indicates that 1,6-HD should block interaction of PR20 with hnRNPA2, and work as an inhibitor against phase separation and aggregation. These data suggest that 1,6-HD could interact with PRn peptides and/or the IDR of RBPs. On the other hands, present data of ours show that 1,6-HD binds to beta actin in nuclear extract of HeLa cells, suggesting that the beta actin is novel target molecule of 1,6-HD other than PRn peptides and the IDR of RBPs.

1,6-HD disrupts various cellular structures of membrane-less organelles which are based upon phase separations, in vitro and in vivo [31-33, 61, 64], while 1,6-HD has no effect on Endoplasmic Reticulum and mitochondria [65]. Furthermore, 1,6-HD has been reported to destroy the actin assembly of cytoskeleton organization [65], suggesting relation between inhibition of phase separation by 1,6-HD and function of actin. Our observation on the binding of 1,6-HD to beta actin might represent the data showing its disruption of the beta actin assembly in yeast and human HeLa cells [65]. Actin assembly is involved in phase separation in relation to cytoskeleton dynamics. It is possible that binding of 1,6-HD to beta actin might contribute to regulation of phase separation.

The actin cytoskeleton is a critical regulator of cytoplasmic architecture and mechanics, essential in numerous physiological processes. Assemblies of actin are regulated by phase separation in vitro [50] and in vivo systems [51]. Microscopic observation with cross-linked actin bundles revealed a liquid phase of actin filaments in the presence of the physiological cross-linker, filamin [50]. Filamin condenses short actin filaments into spindle-shaped droplets termed tactoids. The cross-linker filamin density controls the droplet shape and deformation timescales, consistent with a 
variable interfacial tension and viscosity. These observations show a conceivable mechanism to control organization, morphology, and dynamics of the actin cytoskeleton through phase separation. Then, it is likely that actin works as a regulator for phase separation and resultant precipitation formation, confirming that the binding of 1,6-HD to beta actin should play a role in its inhibition to phase separation in cellular programs.

\section{Conclusion}

In order to explore a regulatory mechanism of phase separation and resultant aggregation that causes neurodegenerative diseases including ALS, we have employed affinity chromatography using a phase separation inhibitor, 1,6-HD. These experiments performed to search the initial event of inhibition of phase separation. We demonstrated binding of $1,6-\mathrm{HD}$ to beta actin in NE. This finding indicates that interaction of 1,6-HD with beta actin could initiate inhibition of phase separation. Previous observation that 1,6-HD disrupts actin assemblies in the cytoskeleton of eukaryotic cells presents possibility of active control of actin cellular functions by the inhibition of phase separation prompted by 1,6-HD.

In the dendritic spine, actin is involved in neuronal functions. The actin assemblies play a pivotal role in long-term potentiation in the human central nervous system upon morphological alteration of the dendritic spine [66], suggesting that 1,6-HD could control memory formation in the human brain. Phase separation and precipitation has harmful effect on the motor neuron and cause neuronal death related to ALS. Inhibition of the precipitation or formation of inclusion bodies in the motor neuron of ALS patients will provide potential therapeutics with a seed for a drug against ALS.

Phase separation and precipitation elicited by the IDP conserved in the evolution over eukaryotic cells. The harmful precipitation should be restrained by the inhibitory systems of phase separation. The prevention of the precipitation would serve as a risk management action to maintain it for efficient biological activities. These prospects could contribute to future investigation of phase separation in divergent biological programs. This will enhance elucidation of open questions to be addressed in the future endeavors.

\section{Acknowledgements}

The authors would thank for fruitful and constructive discussion by all members of the Kurokawa laboratory. The authors also thank Dr. Christopher K. Glass and Dr, Michael Geoffrey Rosenfeld for profound insight into development of projects. This study was supported by Grant-in-Aid for Scientific Research (C: 18K06939).

\section{Appendix}

(a)

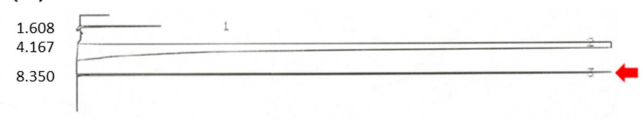

(b)

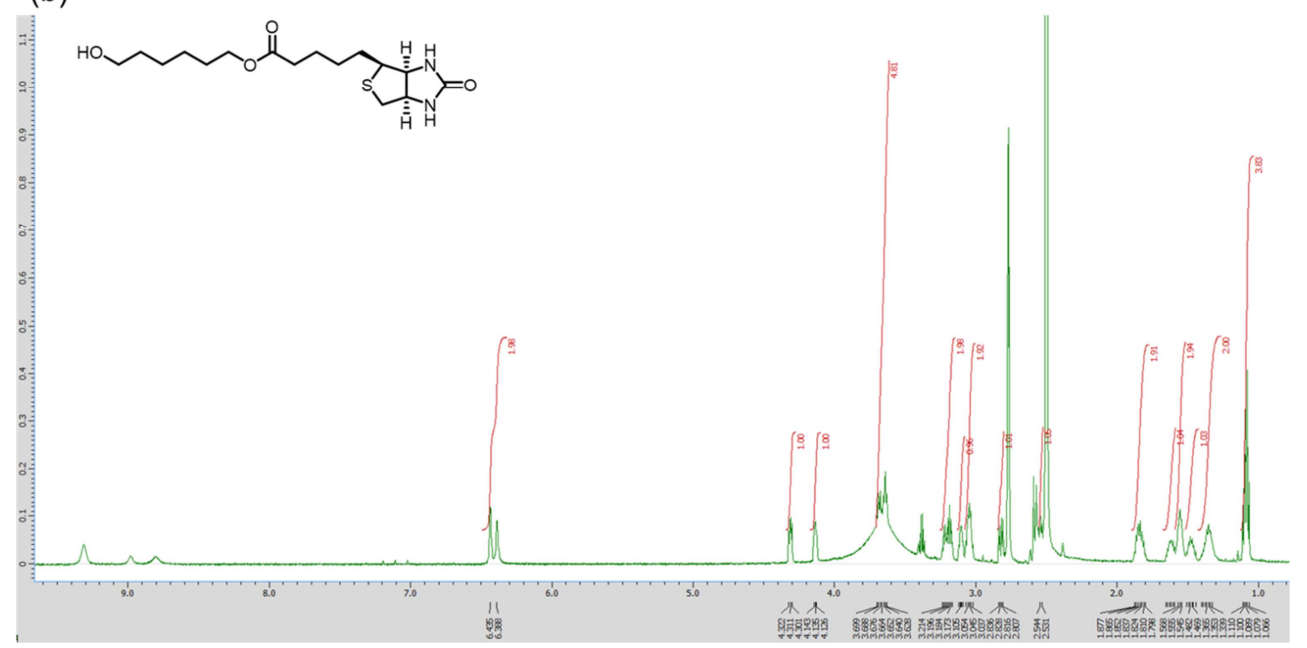

Figure 5. Biotinylated 1,6-hexanediol (bio-1,6-HD).

(a) The HPLC spectrum of Biotinylated 1,6-hexanediol. Conditions: $0.1 \%$ TFA containing 0-100\% acetonitrile over a linear gradient for 20 min at a flow rate of $1.0 \mathrm{~mL} / \mathrm{min}$ detected at $205 \mathrm{~nm}$. The retention time was $8.350 \mathrm{~min}$. (b) The chemical structure of Biotinylated 1,6-hexanediol and the ${ }^{1} \mathrm{H}-\mathrm{NMR}$ (600 MHz, DMSO- $\left.d_{6}\right)$ spectrum of Biotinylated 1,6-hexanediol. $\delta 6.44\left(\mathrm{~s}, 1 \mathrm{H}, \mathrm{H}_{\mathrm{a}}\right), 6.39\left(\mathrm{~s}, 1 \mathrm{H}, \mathrm{H}_{\mathrm{a}}\right), 4.31\left(\mathrm{t}, J=6.3 \mathrm{~Hz}, 1 \mathrm{H}, \mathrm{H}_{\mathrm{b}}\right), 4.14\left(\mathrm{t}, J=5.1 \mathrm{~Hz}, 1 \mathrm{H}, \mathrm{H}_{\mathrm{b}}\right), 3.70-3.63(\mathrm{~m}, 5 \mathrm{H}$, $\mathrm{H}_{\mathrm{f}}$ ), 3.24-3.17 (m, $\left.2 \mathrm{H}, \mathrm{H}_{\mathrm{e}}\right), 3.10\left(\mathrm{q}, J=6.2 \mathrm{~Hz}, 1 \mathrm{H}, \mathrm{H}_{\mathrm{c}}\right), 3.05$ (quin, $\left.J=7.5 \mathrm{~Hz}, 2 \mathrm{H}, \mathrm{H}_{\mathrm{e}}\right), 2.82\left(\mathrm{dd}, J=12.0 \mathrm{~Hz}, 4.8 \mathrm{~Hz}, 1 \mathrm{H}, \mathrm{H}_{\mathrm{d}}\right), 2.54\left(\mathrm{~d}, J=7.8 \mathrm{~Hz}, 1 \mathrm{H}, \mathrm{H}_{\mathrm{d}}\right), 1.88-1.80$ $\left(\mathrm{m}, 2 \mathrm{H}, \mathrm{H}_{\mathrm{e}}\right), 1.65-1.59\left(\mathrm{~m}, 1 \mathrm{H}, \mathrm{H}_{\mathrm{e}}\right), 1.57-1.52\left(\mathrm{~m}, 2 \mathrm{H}, \mathrm{H}_{\mathrm{e}}\right), 1.51-1.44\left(\mathrm{~m}, 1 \mathrm{H}, \mathrm{H}_{\mathrm{e}}\right), 1.40-1.33\left(2 \mathrm{H}, \mathrm{m}_{\mathrm{e}} \mathrm{H}_{\mathrm{e}}\right), 1.09\left(\mathrm{quin}, J=6.6 \mathrm{~Hz}, 4 \mathrm{H}, \mathrm{H}_{\mathrm{e}}\right)$. 
(c)

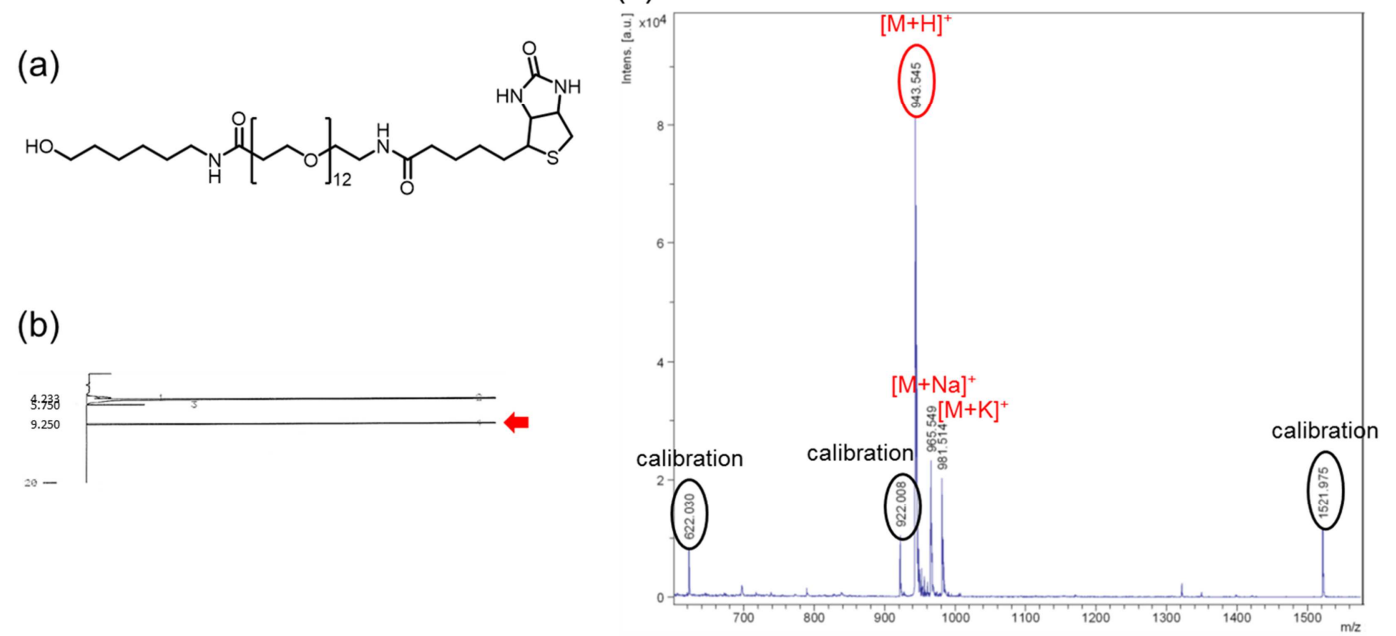

Figure 6. Biotinylated $P E G_{12}-N H$-hexanol (bio-1,6-HD plus).

EZ-Link ${ }^{\mathrm{TM}}$ NHS-PEG 12 -Biotin $250 \mathrm{mM}$ in DMF $21.25 \mu \mathrm{L}(5.3 \mu \mathrm{mol})$ was mixed with $128.3 \mu \mathrm{L}$ of DMF, 6-amino-1-hexanol (0.78 mg, 1.2 equiv.), and DIEA $(1.08 \mu \mathrm{L}, 1.2$ equiv.) and then stirred at room temprature for 2.5 hours. The mixture was purified by reverse-phase HPLC and $3.2 \mathrm{mg}$ of target material (colorless oil) was obtained ( $3.4 \mu \mathrm{mol}$, yield: $64 \%$, analytical HPLC: $\mathrm{tR}=9.3 \mathrm{~min}$. MALDI-TOF MS: m/z calcd for $\mathrm{C}_{43} \mathrm{H}_{83} \mathrm{~N}_{4} \mathrm{O}_{16} \mathrm{~S}^{+}[\mathrm{M}+\mathrm{H}]^{+} 943.54$, found; 943.55$)$.

\section{References}

[1] Vance C, Rogelj B, Hortobagyi T, De Vos KJ, Nishimura AL, Sreedharan J, Hu X, Smith B, Ruddy D, Wright P, et al. (2009) Mutations in FUS, an RNA processing protein, cause familial amyotrophic lateral sclerosis type 6. Science 323, 1208-1211, doi: 323/5918/1208 [pii] 10.1126/science.1165942.

[2] Kwiatkowski TJ, Jr., Bosco DA, Leclerc AL, Tamrazian E, Vanderburg CR, Russ C, Davis A, Gilchrist J, Kasarskis EJ, Munsat T, et al. (2009) Mutations in the FUS/TLS gene on chromosome 16 cause familial amyotrophic lateral sclerosis. Science 323, 1205-1208, doi: 323/5918/1205 [pii] 10.1126/science. 1166066 .

[3] Mackenzie IR \& Neumann M (2016) Molecular neuropathology of frontotemporal dementia: insights into disease mechanisms from postmortem studies. Journal of neurochemistry 138 Suppl 1, 54-70, doi: 10.1111/jnc.13588.

[4] Ludolph AC, Brettschneider J \& Weishaupt JH (2012) Amyotrophic lateral sclerosis. Current opinion in neurology 25, 530-535, doi: 10.1097/WCO.0b013e328356d328.

[5] Arbab M, Baars S \& Geijsen N (2014) Modeling motor neuron disease: the matter of time. Trends in neurosciences 37 , 642-652, doi: 10.1016/j.tins.2014.07.008.

[6] Rosen DR, Siddique T, Patterson D, Figlewicz DA, Sapp P, Hentati A, Donaldson D, Goto J, O'Regan JP, Deng HX, et al. (1993) Mutations in $\mathrm{Cu} / \mathrm{Zn}$ superoxide dismutase gene are associated with familial amyotrophic lateral sclerosis. Nature 362, 59-62, doi: 10.1038/362059a0.

[7] Sreedharan J, Blair IP, Tripathi VB, Hu X, Vance C, Rogelj B, Ackerley S, Durnall JC, Williams KL, Buratti E, et al. (2008) TDP-43 mutations in familial and sporadic amyotrophic lateral sclerosis. Science 319, 1668-1672, doi: $10.1126 /$ science. 1154584 .

[8] Lagier-Tourenne C \& Cleveland DW (2009) Rethinking ALS: the FUS about TDP-43. Cell 136, 1001-1004, doi:

S0092-8674(09)00263-3 [pii]10.1016/j.cell.2009.03.006.

[9] Taylor JP, Brown Jr RH \& Cleveland DW (2016) Decoding ALS: from genes to mechanism. Nature 539, 197-206, doi: 10.1038/nature20413.

[10] Sadek H, Hannack B, Choe E, Wang J, Latif S, Garry MG, Garry DJ, Longgood J, Frantz DE, Olson EN, et al. (2008) Cardiogenic small molecules that enhance myocardial repair by stem cells. Proceedings of the National Academy of Sciences 105, 6063-6068, doi: 10.1073/pnas.0711507105.

[11] Kato M, Han TW, Xie S, Shi K, Du X, Wu LC, Mirzaei H, Goldsmith EJ, Longgood J, Pei J, et al. (2012) Cell-free formation of RNA granules: low complexity sequence domains form dynamic fibers within hydrogels. Cell 149, 753-767, doi: 10.1016/j.cell.2012.04.017.

[12] Kurokawa R \& Bando T (2016) Three-Dimensional Structure of RNA-Binding Protein TLS Co-Crystallized with Biotinylated Isoxazole. Biomedical Sciences 2, 1-10, doi: 10.11648/j.rnat.20160201.11.

[13] Ueda N, Kashiwazaki G, Bando T \& Kurokawa R (2017) Biotin-Lys-His Blocks Aggregation of RNA-binding Protein TLS, a Cause of Amyotrophic Lateral Sclerosis. Biomedical Sciences 3, 67-77, doi: doi: 10.11648/j.bs.20170304.11.

[14] Han TW, Kato M, Xie S, Wu LC, Mirzaei H, Pei J, Chen M, Xie Y, Allen J, Xiao G, et al. (2012) Cell-free formation of RNA granules: bound RNAs identify features and components of cellular assemblies. Cell 149, 768-779, doi: 10.1016/j.cell.2012.04.016.

[15] Lorković ZJ \& Barta A (2002) Genome analysis: RNA recognition motif (RRM) and $\mathrm{K}$ homology $(\mathrm{KH})$ domain RNA-binding proteins from the flowering plant Arabidopsis thaliana. Nucleic Acids Research 30, 623-635, doi: 10.1093/nar/30.3.623.

[16] Farina KL, Hüttelmaier S, Musunuru K, Darnell R \& Singer RH (2003) Two ZBP1 KH domains facilitate $\beta$-actin mRNA localization, granule formation, and cytoskeletal attachment. J Cell Biol 160, 77-87, doi: 10.1083/jcb.200206003. 
[17] Gerstberger S, Hafner M \& Tuschl T (2014) A census of human RNA-binding proteins. Nature Reviews Genetics 15, 829, doi: 10.1038/nrg3813https://www.nature.com/articles/nrg3813\#su pplementary-information.

[18] Patel A, Lee Hyun O, Jawerth L, Maharana S, Jahnel M, Hein Marco Y, Stoynov S, Mahamid J, Saha S, Franzmann Titus M, et al. (2015) A Liquid-to-Solid Phase Transition of the ALS Protein FUS Accelerated by Disease Mutation. Cell 162, 1066-1077, doi: 10.1016/j.cell.2015.07.047.

[19] Niaki AG, Sarkar J, Cai X, Rhine K, Vidaurre V, Guy B, Hurst M, Lee JC, Koh HR, Guo L, et al. (2020) Loss of Dynamic RNA Interaction and Aberrant Phase Separation Induced by Two Distinct Types of ALS/FTD-Linked FUS Mutations. Molecular Cell 77, 82-94. e84, doi: https://doi.org/10.1016/j.molcel.2019.09.022.

[20] Yoshizawa T, Nozawa R-S, Jia TZ, Saio T \& Mori E (2020) Biological phase separation: cell biology meets biophysics. Biophysical Reviews 12, 519-539, doi: 10.1007/s12551-020-00680-x.

[21] Yoshizawa T, Ali R, Jiou J, Fung HYJ, Burke KA, Kim SJ, Lin Y, Peeples WB, Saltzberg D, Soniat M, et al. (2018) Nuclear Import Receptor Inhibits Phase Separation of FUS through Binding to Multiple Sites. Cell 173, 693-705.e622, doi: https://doi.org/10.1016/j.cell.2018.03.003.

[22] Qamar S, Wang G, Randle SJ, Ruggeri FS, Varela JA, Lin JQ, Phillips EC, Miyashita A, Williams D, Ströhl F, et al. (2018) FUS Phase Separation Is Modulated by a Molecular Chaperone and Methylation of Arginine Cation-\&\#x3c0; Interactions. Cell 173, 720-734.e715, doi: 10.1016/j.cell.2018.03.056.

[23] Sun S, Ling S-C, Qiu J, Albuquerque CP, Zhou Y, Tokunaga S, Li H, Qiu H, Bui A, Yeo GW, et al. (2015) ALS-causative mutations in FUS/TLS confer gain and loss of function by altered association with SMN and U1-snRNP. Nature communications 6, doi: 10.1038/ncomms7171.

[24] Turner MR, Hardiman O, Benatar M, Brooks BR, Chio A, de Carvalho M, Ince PG, Lin C, Miller RG, Mitsumoto H, et al. (2013) Controversies and priorities in amyotrophic lateral sclerosis. The Lancet Neurology 12, 310-322, doi: 10.1016/S1474-4422(13)70036-X.

[25] Murakami T, Qamar S, Lin JQ, Schierle GS, Rees E, Miyashita A, Costa AR, Dodd RB, Chan FT, Michel CH, et al. (2015) ALS/FTD Mutation-Induced Phase Transition of FUS Liquid Droplets and Reversible Hydrogels into Irreversible Hydrogels Impairs RNP Granule Function. Neuron 88, 678-690, doi: 10.1016/j.neuron.2015.10.030.

[26] Lagier-Tourenne C, Polymenidou M \& Cleveland DW (2010) TDP-43 and FUS/TLS: emerging roles in RNA processing and neurodegeneration. Hum Mol Genet 19, R46-64, doi: ddq137 [pii] 10.1093/hmg/ddq137.

[27] DeJesus-Hernandez M, Mackenzie IR, Boeve BF, Boxer AL, Baker M, Rutherford NJ, Nicholson AM, Finch NA, Flynn H, Adamson J, et al. (2011) Expanded GGGGCC hexanucleotide repeat in noncoding region of C9ORF72 causes chromosome 9p-linked FTD and ALS. Neuron 72, 245-256, doi: 10.1016/j.neuron.2011.09.011.

[28] Renton AE, Majounie E, Waite A, Simon-Sanchez J, Rollinson S, Gibbs JR, Schymick JC, Laaksovirta H, van Swieten JC, Myllykangas L, et al. (2011) A hexanucleotide repeat expansion in C9ORF72 is the cause of chromosome 9p21-linked ALS-FTD. Neuron 72, 257-268, doi: 10.1016/j.neuron.2011.09.010.

[29] Jucker M \& Walker LC (2013) Self-propagation of pathogenic protein aggregates in neurodegenerative diseases. Nature 501, 45-51, doi: 10.1038/nature12481.

[30] Jain A \& Vale RD (2017) RNA phase transitions in repeat expansion disorders. Nature 546, 243-247, doi: 10.1038 /nature22386.

[31] Patel SS, Belmont BJ, Sante JM \& Rexach MF (2007) Natively unfolded nucleoporins gate protein diffusion across the nuclear pore complex. Cell 129, 83-96, doi: 10.1016/j.cell.2007.01.044.

[32] Updike DL, Hachey SJ, Kreher J \& Strome S (2011) P granules extend the nuclear pore complex environment in the $\mathrm{C}$. elegans germ line. J Cell Biol 192, 939-948, doi: $10.1083 /$ jcb.201010104.

[33] Kroschwald S, Maharana S, Mateju D, Malinovska L, Nuske E, Poser I, Richter D \& Alberti S (2015) Promiscuous interactions and protein disaggregases determine the material state of stress-inducible RNP granules. Elife 4, e06807, doi: 10.7554/eLife.06807.

[34] Lin Y, Mori E, Kato M, Xiang S, Wu L, Kwon I \& McKnight SL (2016) Toxic PR Poly-Dipeptides Encoded by the C9orf72 Repeat Expansion Target LC Domain Polymers. Cell 167, 789-802.e712, doi: 10.1016/j.cell.2016.10.003.

[35] Wang X, Arai S, Song X, Reichart D, Du K, Pascual G, Tempst P, Rosenfeld MG, Glass CK \& Kurokawa R (2008) Induced ncRNAs allosterically modify RNA-binding proteins in cis to inhibit transcription. Nature 454, 126-130, doi: nature06992 [pii]10.1038/nature06992.

[36] Cui W, Yoneda R, Ueda N \& Kurokawa R (2018) Arginine methylation of translocated in liposarcoma (TLS) inhibits its binding to long noncoding RNA, abrogating TLS-mediated repression of $\mathrm{CBP} / \mathrm{p} 300$ activity. J Biol Chem 293, 10937-10948, doi: 10.1074/jbc.RA117.000598.

[37] Yoneda R, Suzuki S, Mashima T, Kondo K, Nagata T, Katahira M \& Kurokawa R (2016) The binding specificity of Translocated in LipoSarcoma/FUsed in Sarcoma with lncRNA transcribed from the promoter region of cyclin D1. Cell \& bioscience 6, 4, doi: 10.1186/s13578-016-0068-8.

[38] Yoneda R, Ueda N, Uranishi K, Hirasaki M \& Kurokawa R (2020) Long noncoding RNA pncRNA-D reduces cyclin D1 gene expression and arrests cell cycle through RNA m (6) A modification. J Biol Chem 295, 5626-5639, doi: 10.1074/jbc.RA119.011556.

[39] Du K, Arai S, Kawamura T, Matsushita A \& Kurokawa R (2011) TLS and PRMT1 synergistically coactivate transcription at the survivin promoter through TLS arginine methylation. Biochem Biophys Res Commun 404, 991-996, doi: S0006-291X(10)02335-1[pii] 10.1016/j.bbrc.2010.12.097.

[40] Shin Y, Chang Y-C, Lee DSW, Berry J, Sanders DW, Ronceray P, Wingreen NS, Haataja M \& Brangwynne CP (2018) Liquid Nuclear Condensates Mechanically Sense and Restructure the Genome. Cell 175, 1481-1491.e1413, doi: 10.1016/j.cell.2018.10.057.

[41] Hyman AA, Weber CA \& Jülicher F (2014) Liquid-Liquid Phase Separation in Biology. Annual Review of Cell and Developmental Biology 30, 39-58, doi: 10.1146/annurev-cellbio-100913-013325. 
[42] Baumgart T, Hammond AT, Sengupta P, Hess ST, Holowka DA, Baird BA \& Webb WW (2007) Large-scale fluid/fluid phase separation of proteins and lipids in giant plasma membrane vesicles. Proceedings of the National Academy of Sciences 104, 3165-3170, doi: 10.1073/pnas.0611357104.

[43] Strom AR, Emelyanov AV, Mir M, Fyodorov DV, Darzacq X \& Karpen GH (2017) Phase separation drives heterochromatin domain formation. Nature 547, 241-245, doi: 10.1038 /nature22989.

[44] Alberti S, Gladfelter A \& Mittag T (2019) Considerations and Challenges in Studying Liquid-Liquid Phase Separation and Biomolecular Condensates. Cell 176, 419-434, doi: https://doi.org/10.1016/j.cell.2018.12.035.

[45] Boeynaems S, Alberti S, Fawzi NL, Mittag T, Polymenidou M, Rousseau F, Schymkowitz J, Shorter J, Wolozin B, Van Den Bosch L, et al. (2018) Protein Phase Separation: A New Phase in Cell Biology. Trends in Cell Biology 28, 420-435, doi: https://doi.org/10.1016/j.tcb.2018.02.004.

[46] Brangwynne CP, Eckmann CR, Courson DS, Rybarska A, Hoege C, Gharakhani J, Jülicher F \& Hyman AA (2009) Germline P Granules Are Liquid Droplets That Localize by Controlled Dissolution/Condensation. Science 324, 1729-1732, doi: $10.1126 /$ science. 1172046 .

[47] Brangwynne CP, Mitchison TJ \& Hyman AA (2011) Active liquid-like behavior of nucleoli determines their size and shape in Xenopus laevis oocytes. Proceedings of the National Academy of Sciences 108, 4334-4339, doi: 10.1073/pnas.1017150108.

[48] Wippich F, Bodenmiller B, Trajkovska MG, Wanka S, Aebersold R \& Pelkmans L (2013) Dual specificity kinase DYRK3 couples stress granule condensation/dissolution to mTORC1 signaling. Cell 152, 791-805, doi: 10.1016/j.cell.2013.01.033.

[49] Strzelecka M, Trowitzsch S, Weber G, Lührmann R, Oates AC \& Neugebauer KM (2010) Coilin-dependent snRNP assembly is essential for zebrafish embryogenesis. Nature Structural \& Molecular Biology 17, 403-409, doi: 10.1038/nsmb.1783.

[50] Weirich KL, Banerjee S, Dasbiswas K, Witten TA, Vaikuntanathan S \& Gardel ML (2017) Liquid behavior of cross-linked actin bundles. Proceedings of the National Academy of Sciences 114, 2131-2136, doi: 10.1073/pnas.1616133114.

[51] Case LB, Zhang X, Ditlev JA \& Rosen MK (2019) Stoichiometry controls activity of phase-separated clusters of actin signaling proteins. Science 363, 1093-1097, doi: 10.1126/science.aau6313.

[52] Boija A, Klein IA, Sabari BR, Dall'Agnese A, Coffey EL, Zamudio AV, Li CH, Shrinivas K, Manteiga JC, Hannett NM, et al. (2018) Transcription Factors Activate Genes through the Phase-Separation Capacity of Their Activation Domains. Cell 175, 1842-1855.e1816, doi: 10.1016/j.cell.2018.10.042.

[53] Wei MT, Chang YC, Shimobayashi SF, Shin Y, Strom AR \& Brangwynne CP (2020) Nucleated transcriptional condensates amplify gene expression. Nat Cell Biol, doi: 10.1038/s41556-020-00578-6.

[54] Nair SJ, Yang L, Meluzzi D, Oh S, Yang F, Friedman MJ, Wang S, Suter T, Alshareedah I, Gamliel A, et al. (2019) Phase separation of ligand-activated enhancers licenses cooperative chromosomal enhancer assembly. Nature Structural \& Molecular Biology 26, 193-203, doi: 10.1038/s41594-019-0190-5.
[55] Kanaan NM, Hamel C, Grabinski T \& Combs B (2020) Liquid-liquid phase separation induces pathogenic tau conformations in vitro. Nature Communications 11, 2809, doi: 10.1038/s41467-020-16580-3.

[56] Ambadipudi S, Biernat J, Riedel D, Mandelkow E \& Zweckstetter M (2017) Liquid-liquid phase separation of the microtubule-binding repeats of the Alzheimer-related protein Tau. Nature Communications 8, 275, doi: 10.1038/s41467-017-00480-0.

[57] Wegmann S, Eftekharzadeh B, Tepper K, Zoltowska KM, Bennett RE, Dujardin S, Laskowski PR, MacKenzie D, Kamath T, Commins C, et al. (2018) Tau protein liquid-liquid phase separation can initiate tau aggregation. Embo J 37, e98049, doi: 10.15252/embj.201798049.

[58] Mackenzie IR, Nicholson AM, Sarkar M, Messing J, Purice MD, Pottier C, Annu K, Baker M, Perkerson RB, Kurti A, et al. (2017) TIA1 Mutations in Amyotrophic Lateral Sclerosis and Frontotemporal Dementia Promote Phase Separation and Alter Stress Granule Dynamics. Neuron 95, 808-816.e809, doi: https://doi.org/10.1016/j.neuron.2017.07.025.

[59] Hofweber M, Hutten S, Bourgeois B, Spreitzer E, Niedner-Boblenz A, Schifferer M, Ruepp M-D, Simons M, Niessing D, Madl T, et al. (2018) Phase Separation of FUS Is Suppressed by Its Nuclear Import Receptor and Arginine Methylation. Cell 173, 706-719. e713, doi: https://doi.org/10.1016/j.cell.2018.03.004.

[60] Monahan Z, Ryan VH, Janke AM, Burke KA, Rhoads SN, Zerze GH, O'Meally R, Dignon GL, Conicella AE, Zheng W, et al. (2017) Phosphorylation of the FUS low-complexity domain disrupts phase separation, aggregation, and toxicity. Embo J 36, 2951-2967, doi: 10.15252/embj.201696394.

[61] Molliex A, Temirov J, Lee J, Coughlin M, Kanagaraj AP, Kim HJ, Mittag T \& Taylor JP (2015) Phase separation by low complexity domains promotes stress granule assembly and drives pathological fibrillization. Cell 163, 123-133, doi: 10.1016/j.cell.2015.09.015.

[62] Finkelstein A (1976) Water and nonelectrolyte permeability of lipid bilayer membranes. J Gen Physiol 68, 127-135, doi: 10.1085/jgp.68.2.127.

[63] Kwon SC, Yi H, Eichelbaum K, Fohr S, Fischer B, You KT, Castello A, Krijgsveld J, Hentze MW \& Kim VN (2013) The RNA-binding protein repertoire of embryonic stem cells. Nature structural \& molecular biology 20, 1122-1130, doi: $10.1038 /$ nsmb. 2638

[64] Ribbeck K \& Gorlich D (2002) The permeability barrier of nuclear pore complexes appears to operate via hydrophobic exclusion. Embo J 21, 2664-2671, doi: 10.1093/emboj/21.11.2664.

[65] Wheeler JR, Matheny T, Jain S, Abrisch R \& Parker R (2016) Distinct stages in stress granule assembly and disassembly. Elife 5, doi: 10.7554/eLife.18413.

[66] Schatzle P, Esteves da Silva M, Tas RP, Katrukha EA, Hu HY, Wierenga CJ, Kapitein LC \& Hoogenraad CC (2018) Activity-Dependent Actin Remodeling at the Base of Dendritic Spines Promotes Microtubule Entry. Curr Biol 28, 2081-2093 e2086, doi: 10.1016/j.cub.2018.05.004. 